\title{
Principles of Self-Regulation in EFL mediated by Dialogic Tutoring Sessions
}

\author{
Principios de autorregulación en la enseñanza del inglés como \\ lengua extranjera mediados por sesiones de tutoría dialógica
}

\author{
Zorro Rojas, Imelda ${ }^{1}$
}

\begin{abstract}
Students' engagement and determination require the use of self-regulated learning strategies to facilitate adequate preparation. This article reports a research study that looks into how eight instructors, who were trained to promote self-regulation, interact with 18 students of a Bachelor of Arts program in English language teaching in Bogotá. The problem was the prevalence of an instructional model of reproduction of knowledge in the English language classes taken by the 18 students. The pedagogical intervention introduces dialogic tutoring. The instructors' voices, in the role of tutors, and the students' voices, as tutees, were collected in 40 videos, a questionnaire, and a focus group. Grounded theory allowed transposing the identification of patterns, code tagging, and code grouping into concepts. This process generated four principles that worked positively in the promotion of self-regulation in this socially and culturally diverse sample of instructors and students, namely: (1) addressing needs, interests and beliefs; (2) setting goals; (3) scaffolding learning; (4) providing quality feedback.
\end{abstract}

Keywords: autonomy, dialogic tutoring, foreign language, scaffolding, self-regulation.

\section{Resumen}

El compromiso de los estudiantes y su determinación para aprender requieren del uso de estrategias autorreguladoras que faciliten una preparación adecuada. Este artículo reporta una investigación

Imelda Zorro Rojas teaches at the graduate and undergraduate TEFL preparation program at Universidad

Libre de Colombia. Her research interests include pedagogy and autonomous learning. She holds a doctorate in education from Universidad Santo Tomás, Colombia. She has published books and articles in the field of applied linguistics. She leads the research group Didaktikos.

imelda.zorror@unilibre.edu.co

https://orcid.org/0000-0002-5436-8551

Received: November 23 ${ }^{\text {rd }}, 2018$. Accepted February $10^{\text {th }}, 2019$

This article is licensed under a Creative Commons Attribution-NonCommercial-NoDerivatives 4.0 International License. License Deed can be consulted at https://creativecommons.org/licenses/by-nc-nd/4.0/ 
que indagó cómo ocho docentes, que fueron entrenados en promover la autorregulación, interactuaron con 18 estudiantes de un programa de formación de profesores de inglés como lengua extranjera de Bogotá. El problema consistía en la prevalencia de un modelo instruccional repetitivo del conocimiento en las clases de inglés que tomaban 18 estudiantes del programa. La intervención pedagógica presentó la tutoría dialógica. Las voces de los ocho instructores-tutores y de los 18 estudiantes-tutoriados fueron registradas en 40 videos, en una encuesta y en un grupo focal. La teoría fundamentada permitió la identificación de patrones y la asignación de códigos a los datos, que fueron luego agrupados en conceptos. En este proceso, surgieron cuatro principios que contribuyeron a promover la autorregulación en esta muestra social y culturalmente diversa de docentes y estudiantes: 1. el abordaje de las necesidades, intereses y creencias, 2. la formulación de objetivos, 3. el andamiaje en el aprendizaje, y 4. la provisión de realimentación efectiva.

Palabras clave: autonomía, tutoría dialógica, lengua extranjera, andamiaje, autorregulación.

\section{Introduction}

Attention to self-regulation has grown in all disciplines. Despite this surge in interest, classroom practices seem to continue being teacher-centered. This paper reports an inductive qualitative study that examined the academic processes for English language learning in a B.A. in English Language Teaching (ELT) program, in which there was evidence of teachercenteredness and little evidence of Self-Regulated Learning (SRL). For Nakata (2014), researchers and educators can offer better support if they know about SRL theories which address these two questions: Why is SRL important for promoting knowledge acquisition? How can it contribute to autonomy?

The problem is that, in most tasks, students gave evidence of little or no planning for the English language classes. This suggested that they had very little degree of control; therefore, instruction should focus on co-creating optimal conditions with students for managing their own learning. In the survey questionnaire (Appendix A) several students indicated that they would rather have the instructor explain content than look it up on their own. This suggests dependence. These factors translated into dissatisfaction with how classes were run. In the same survey, the 18 students' perception of agency was low; they felt that their efforts for learning English were insufficient to develop proficiency when compared to what they could understand or do with English outside the classroom. The results of the questionnaire also indicated that current teaching fulfilled an instrumental role of transmitting information without stimulating deep understanding of how English works. Furthermore, the participants' behaviors of putting little effort into their studies were associated with unclear purposes, short and long-term goals, and paths to follow.

In teacher Education, SRL has transcendence; future in-service teachers will, in turn, lead others. Cuesta, Anderson, and McDougald (as cited in Banegas, 2017) found a lack of preparation in SRL in a study with 40 Colombian pre-service teachers of English. I 
concur with their assertion that there are challenges to meet for "understanding the distinct situations of young learners who can develop SRL habits and skills from the beginning of their formal educational processes and adult learners, needing to unlearn years of dependent learning habits as well as learn new SRL habits, especially if these adults are to foster SRL in others" (p. 121).

The pedagogical intervention created for this current study consisted of training the eight instructors in dialogic tutoring to account for the problem of the students' lack of auto-regulation strategies. The localized pedagogy of co-construction of knowledge to promote SRL was mediated by dialogic tutoring. For Sarangi (2000), dialogic tutoring has to do with analyzing the types of discourse to determine the type of action to be conducted. The 20-hour training of the eight teacher educators of the B.A. program, henceforth called instructors/tutors, followed the premise that: "Dialogic teaching involves ongoing talk between teacher and students, not just teacher-presentation. Through dialogue, teachers can elicit students' everyday 'common sense' perspectives, engage with their developing ideas and help them overcome misunderstandings." (University of Cambridge, 2017, p.1) From the problem of the dissatisfaction identified in the diagnosis and the 18 participant instructors' decision to promote autonomy, this question guided the inquiry: How can learners and instructors co-construct self-regulated learning in dialogic tutoring sessions?

The research study then seeks to establish personal agency in terms of Harris, Brown, and Dargusch (2018), who view agency as a process wherein instructional objectives are achieved through volitional direction and tacit involvement in learning. The following section expands on the central concepts of the inquiry.

\section{Conceptual Framework}

Socio-cultural theory. A key feature of Sociocultural Theory (SCT) in human development is that higher order functions develop out of social interaction. Vygotsky (1978) argues that someone's development cannot be understood by a study of the individual, i.e., that investigating cognition requires not isolating it from social context. That is why I examined the context in which the participants act. The interaction of an experienced teacher educator guides and supports the actions of the novice learner. However, I wondered if mediation progressed from dependency to SRL, which revolves around these questions: Was it done? How did it happen? Which factors were associated with this change?

The purpose of training the instructors was to propitiate a more effective dialogue that boosts the participating students' potential for autonomous learning. The training sessions insisted on scaffolding learning with the use of an instructional module pack (Kanda University, 2007) about oriented goals. With this (what? view? practice?), social interaction 
and collaboration became central. Furthermore, the training was meant to leave behind the power imbalance between students' local needs and the instructors' personal or institutional agendas (Freire, 1970). The new role entailed a transformation for the instructor to become a mediator (Lantolf \& Pavlenko, 2001).

Self-regulation and autonomous language learning. For Kluwe (1987), the term Self-Regulated Learning (SRL) responds to the classic questions that usually arise when cognitive tasks are tackled: Planning (What am I going to do? How am I going to do it?), monitoring and supervising (What am I doing? How am I doing it?), and evaluating (How well or badly am I doing it?).

Students can take control (Benson, 2001) or self-direct their learning (Holec, 1981) in order to interact and use the appropriate resources, strategies and materials (Lantolf, 2000). Other authors have demonstrated that self-regulation has to do with study setting, establishing goals, time management, seeking for help, self-evaluation, attitudes, behaviors, strategies, and self-monitoring (Gu, 2010; Magno, 2009).

For Zimmerman and Bandura (as cited in Boekaerts, Pintrich, \& Zeidner, 2005) attaining self-regulation has to do with three perspectives: socio-cognitive, behavioral, and environmental factors. For these authors, the triadic processes intervene not only in behavioral skills to manage contingencies, but also in the knowledge and in the sense of personal agency to enact this expertise in relevant contexts. Personal agency beliefs express one's views as to whether one is capable of performing a given task.

For Benson (2011) autonomy is multidimensional; it takes different forms according to the person, the setting, and multiple contextual and micro-contextual factors. The individual makes the decision to progressively assume a role to move from dependence to interdependence; from acquiring knowledge in the classroom to socializing it outside.

Similarly, Little (as cited in Gathercole, 1991) claims that autonomous language learning consists of "the capacity for detachment, critical reflection, decision making and independent action." (p. 4) It is not a specific feature, it is a capacity that will grow by practice, or be lost through inactivity. For McGarry (1995), "human beings are autonomous in relation to a particular task when they are able to perform that task (1) without assistance, (2) beyond the immediate context in which they acquired the knowledge and skills on which successful task performance depends, and (3) flexibly, considering the special requirements of particular circumstances" (p. 1).

Dialogic tutoring. Language is a socially constructed sign-system that allows consciousness to arise (Bakhtin, 1981; Voloshinov, 1976). In this research study, the dialogue tutor-tutee aimed at raising awareness on the purpose, the ways, and the root of misconceptions about learning another language. In this project, eight university instructors, 
two of which were native-speaker language assistants attended a 20-hour training course in dialogic tutoring. Then they coached 18 students to cope with the English language tasks and more importantly, to co-construct a pathway agreeing to plan, execute and fulfill goals that enhance their English language proficiency (Gardner \& Miller, 1996). Two examples illustrate the use of module pack. Tutee 1 and tutor Aida discuss a task, on the topic "idiomatic expressions." This made up part of the tutee's interest. In another excerpt, Aida, the tutor, promoted speaking with Naty, talking about a trip she made. There are more examples in Tables 4, 5, 6 and 7. Tutoring was a place to collaborate with a tutee for identifying problem areas and understanding the work involved in solving them.

I concur with Luidig and Mynard (2012) in that tutoring sessions constitute a moment of counseling established by instructors and students in a more balanced relationship of power in which both aim to work on the new knowledge. Dialogic tutoring goes above-andbeyond language issues. To be successful, tutoring keeps conversation focus directed onto (or toward) the student's purpose and onto the design of a path to advance.

\section{Methodology}

A diagnosis and an intervention took place over a span of 18 months. This research employed Grounded Theory (Strauss \& Corbin, 2002) for the examination of the pieces of data, labeling, and coding. As more data were collected from eight instructors and 18 students, codes were grouped into concepts, and later into categories, which yielded the principles that contributed to SRL. The responses to the students' diagnostic questionnaire allowed the identification of the problem.

The intervention had twenty sessions of two hours. All the sessions were recorded and transcribed. The transcriptions gave an account of the interactions of the participants and allowed knowing the learners' progress and difficulties as well as learning from them (Wells, 2001). Data from the sessions were registered and coded, first manually and then with the software Atlas Ti, which permitted the identification of open and emergent codes. Triangulation derived from comparing and contrasting data from questionnaires (Appendices A and B), 40 transcriptions of video-recordings, and the responses of a focus group (Table 3 below). The inductive qualitative and interpretative analysis (or analyses?) proposed by Grounded Theory meant to determine the effectiveness of dialogues and interactions, and provided the canvas for picturing the data.

\section{Results}

The responses to the student questionnaire, conducted before the intervention (Appendix A), established that heteronomy was constant. Students agreed that most lessons 
were teacher-centered, and affirmed that they became used to having their teachers provide the explanations. On the other hand, 9 of 18 respondents claimed that they did not use English outside class, while 12 responded that they resorted to Spanish to discuss topics in the English class.

Teacher-centeredness and resistance to use English pointed to a general dissatisfaction with what happens in their English class (See Table 1 and Appendix A).

Table 1. Aspects of Students' Dissatisfaction with their classes

- Not to see our progress in proficiency.

- Not to receive individualized attention.

- Not to review the learned topics.

- Not to do classwork on our weaknesses.

- Not to practice what we have learned.

- Not to consider everybody has a different pace.

- Some of our teachers' attitudes.

- Our teachers' methodologies.

- Too much use of web pages with little or no orientation

- Lessons tend to be boring.

- Lack of determination and autonomy from some of us.

This questionnaire also established that planning posed difficulties; half of the students affirmed that they did not set short-term goals. When asked how they self-regulated, they responded, "using exercises from internet/websites, chatting with foreigners, doing repetition of mispronounced words, integrating feedback, correcting quizzes and exams in class, facilitating self-correction, doing extra exercises." In addition, they claimed to be skillful in correcting mistakes, but felt they required more strategies. In other words, they could monitor the course contents, but saw no evidence of enactive feedback for actual use of strategies that would give them confidence.

The data gathered after the intervention, with forty video transcripts, and the instructors' responses, helped respond to this question: How can learners and instructors co-construct selfregulation in dialogic tutoring sessions? The answer was that learners and instructors manage to construct self-regulation when their interactions go beyond the subject matter, and their dialogues address the learners' needs, interests, and set of beliefs. SRL is also constructed by taking time to identify and negotiate goals and by scaffolding in learning. In addition, enactive feedback (response to act on both the content of and on the process to learn) contributes to the construction of SRL. 
In the dialogic tutoring sessions, instructors and students displayed strategies, procedures, resources and decisions to learn English (See Table 2). In addition, students attested to their change of approach and beliefs to tackling the study of the language forms, as well as their ability to communicate. The raw data were grouped in beliefs, autonomy, actions, and evidence of SRL. Table 2 displays the coding and findings established from the density of data.

Table 2. Coding

\begin{tabular}{|c|c|c|c|}
\hline Beliefs About: & Autonomy Level & Actions & $\begin{array}{c}\text { Self-Regulation } \\
\text { (Strategies, Procedures } \\
\text { And Resources) }\end{array}$ \\
\hline $\begin{array}{l}\text { - Teaching a } \\
\text { foreign language } \\
\text { - Second language } \\
\text { acquisition } \\
\text { - Speaking another } \\
\text { language }\end{array}$ & $\begin{array}{l}\text { - Awareness } \\
\text { - Intervention } \\
\text { - Compromise } \\
\text { - Creation } \\
\text { - Transcendence }\end{array}$ & $\begin{array}{l}\text { Tutor'S } \\
\text { - Pathway build up } \\
\text { - Use and evaluation } \\
\text { of a learning } \\
\text { strategy } \\
\text { - Comparison of } \\
\text { strategies for } \\
\text { academic tasks } \\
\text { Tutee'S } \\
\text { - Grammar } \\
\text { Clarification } \\
\text { - Communicative } \\
\text { ability }\end{array}$ & $\begin{array}{ll}\text { - } & \text { Scaffolding/ } \\
\text { - } & \text { searching for help } \\
& \text { self-learnication of } \\
\text { - } & \text { Searching a } \\
& \text { study place } \\
\text { - } & \text { Self-evaluation } \\
\text { - } & \text { Organization } \\
\text { - Use of materials } \\
\text { - } \text { Becoming responsible } \\
\text { - Grammar clarification } \\
\text { - } \text { Communicative skills } \\
\text { - } \text { Roles } \\
\text { - Negotiation of topics } \\
\text { - } \text { Dialogic tutoring } \\
\text { - relationship } \\
\text { and validation by } \\
\text { the instructor. }\end{array}$ \\
\hline
\end{tabular}

The interpretation of behaviors, attitudes, and relationships of the participating instructors and students supported the theorization of new knowledge. The following sections discuss the findings and display the excerpts and other evidences that support them. Participants appear with a pseudonym. The findings are derived from the polyphony of voices. The tutors' voices assessed their experience of dialogic tutoring very positively. The voices of the eight tutors in a focus group appear in Table 3 below. 
Table 3. Responses to the Questionnaire. $N=8$ instructors

\section{What did Dialogic tutoring allow you to do?}

- Identify strengths and weaknesses

- Discover the students' learning styles and strategies.

- Set goals at long, medium and short periods of time.

- Engage learners in topics they care for.

- Propose engaging tasks.

- Promote the use of English in and out of the classroom.

Introduce the purposeful use of ICT tools.

\section{What would you recommend about tutoring?}

- Should be offered by all the instructors (currently half do it)

- Assign time and space to it

\section{Why is it worth promoting Self-Regulation?}

- Provides orientation to learners on the use of resources

- Helps to identify type of learners: Low risk, high risk, dependent, independent and disoriented learners

- Stimulates critical thinking

- Makes clusters to promote cooperative work

Supports independent work

The focus group of eight instructors estimated that dialogic tutoring demanded a change from the traditional role of helping students meet course requirements. They claimed that they needed to become counselors, which is to help people change behaviors in the directions they chose. They also felt they should be more of a guide in mapping a pathway for learning with the students. They also said that dialogic tutoring constituted an innovative methodology that demanded more training.

On the other hand, instructors estimated that the promotion of self-regulation required support from the teaching, managerial and administrative staff in order to administer space, time, materials, and equipment. Under this condition, they argued that the use of a resource center would facilitate independent learning with multimedia and print materials readily available. Similarly, booths would favor individual attention with the degree of confidentiality needed.

In sum, dialogic tutoring allowed instructors to get to know the 18 students' strengths, weaknesses, needs, and interests. They gained insights into how scaffolding contributed to acquisition (Lantolf, 2000; Vygotsky, 1978). They also claimed that participating students improved their command of the language and became more confident. 
Tutoring sessions enabled the understanding of cognitive, metacognitive, motivational, and attitudinal factors which influence self-regulation. Tutoring cleared the pathway and facilitated new roles in a process in which instructors and students dynamize the process of learning to learn (See Appendix B). To attain SRL, I found that tutoring should adhere to these four interconnected principles: (1) addressing needs, interests, and personal agency beliefs recognizes the leaners' awareness of their capabilities to take action conducive to academic achievement; (2) goal-setting reinforces agency; (3) enactive feedback on the content and on the process of learning influences behaviors and agency; and (4) scaffolding individual learning contributes to monitoring, adapting, and assessing achievement.

Finding 1: Needs, interests and personal agency beliefs relate directly to SRL. The first finding suggests that SRL requires the collaboration of teachers and learners to assess needs interests and personal agency beliefs and be prepared to take actions. Table 4 illustrates what learners care for. For example, the dialogs revealed needs of resources, interests in poetry, and beliefs about grammar. These aspects moved tutees 1, 2, 3, 4, and 5 to seek help.

Observing interaction revealed that the students' needs, interests, and beliefs triggered their behaviors. It was perceived that the set of beliefs conditioned the use or abandonment of language learning strategies for tackling tasks or tests (Castillo, 2014). For instance, Naty referred to her experience of trying to use English on a trip to the U.S.A. to assert a true interest in what she is studying. Similarly, Mike wrote a poem as a means to meet his needs and interests in grammar communication, and expression. Yanis' tutees reflected and made learners conscious about using tips previous to an exam; and Lorena and Angela negotiated a topic in tutorials.

Finding 2: Goal-setting relates directly to SRL. The second finding associated with self-regulation was goal-setting. Becoming aware of needs, capabilities, and rejecting false beliefs make goal-setting manageable. The excerpt below represents an action plan in which the resources at hand contribute to the development of cognitive and metacognitive competences.

Cami: Well. In my opinion, I guess is quite similar to writing an essay. You bave to take

I don't know- how you can say that- the topic sentence could be the big goal you can take... I guess... we can handle it in that way, and the small goal may be the order how we write, but I really liked it. (emergent code: comparison of self-learning strategies with academic tasks) 
Table 4. Principle One: Addressing Needs, Interests and Beliefs

\begin{tabular}{|c|c|c|}
\hline Tutees & Accounts & Interpretation \\
\hline 1. Talía & $\begin{array}{l}\text { Using a portfolio as part of the module } \\
\text { pack (explanation with vocabulary in } \\
\text { context, movies, pronunciation) } \\
\text { Tutor (Aida): So, I would like you, first, to } \\
\text { reflect on the process. I'd like your opinion: } \\
\text { How have you felt with the module pack? } \\
\text { Do you come here every week with me and } \\
\text { work with the material, I have provided? } \\
\text { Tutee: Yeah! } \\
\text { Tutor: So, would you like to start } \\
\text { Nataly, tell me your experience? } \\
\text { Tutee: Well, with this I feel so good, because it is } \\
\text { really a way to learn new vocabulary, and is fun } \\
\text { doing this activity, like singing songs, repeating } \\
\text { songs, writing the vocabulary. In addition, } \\
\text { the same happen when watching movies. It is } \\
\text { really a comfortable way of learning. I learn } \\
\text { many things such idiomatic expressions. }\end{array}$ & $\begin{array}{l}\text { The use of an artifact } \\
\text { (Module Pack) helped tutees. } \\
\text { It allowed them to use } \\
\text { reflection and metacognition. } \\
\text { Code: Use of materials } \\
\text { Level of Autonomy: } \\
\text { Transcendence }\end{array}$ \\
\hline 2. Naty & $\begin{array}{l}\text { Evidencing how a need for communicating } \\
\text { contributed to being risky and being part } \\
\text { of the culture; a visit to the U.S.A. } \\
\text { Tutee: (Laughs, nervously/ well/ Bueno; my sister } \\
\text { and me.... have a friend from Long Beach so, well... } \\
\text { we went with her to the mall to buy some clothes and } \\
\text { when the clerk. approached me and I started speaking } \\
\text { English... well I told her to talk. uhm. Uhm... } \\
\text { Tutor (Aida interrupts): Slowly } \\
\text { Naty: In a slowly way she asked me if I } \\
\text { had found everything in the shop. }\end{array}$ & $\begin{array}{l}\text { Being risker-takers to } \\
\text { communicate in the foreign } \\
\text { language makes up part } \\
\text { of getting involved in the } \\
\text { culture; here, scaffolding } \\
\text { provided interest in the } \\
\text { tutor and this allowed } \\
\text { keeping the dialogue going. } \\
\text { Code: Communicating skills } \\
\text { Level of Autonomy: } \\
\text { Intervention }\end{array}$ \\
\hline 3. Mike & $\begin{array}{l}\text { Need for demonstrating creativity } \\
\text { by means of writing. } \\
\text { Feedback on a poem with an English assistant. } \\
\text { State beliefs on the mastery of language } \\
\text { as a venue of expression. Perceives that } \\
\text { clear objectives relate to SRL. }\end{array}$ & $\begin{array}{l}\text { The level of autonomy } \\
\text { (Nunan, 1997) presented in } \\
\text { Mike is between two levels: } \\
\text { creation and transcendence. } \\
\text { Code: Transcendence } \\
\text { Level of Autonomy: } \\
\text { Transcendence }\end{array}$ \\
\hline
\end{tabular}




\begin{tabular}{|c|l|l|}
\hline Tutees & \multicolumn{1}{|c|}{ Accounts } & \multicolumn{1}{c|}{ Interpretation } \\
\hline \multirow{5}{*}{ 4. Martha } & $\begin{array}{l}\text { Discussing a written test. } \\
\text { Yanis, the tutor and a group of } \\
\text { tutees reflect on their exam: } \\
\text { Tutor: } \text { My question is... } \\
\text { Tutor: You mean simple details.... } \\
\text { Martha: You need concentration. } \\
\text { Tutor: } \text { Ok, you need more concentration } \\
\text { and not being overconfident. }\end{array}$ & $\begin{array}{l}\text { The tutor reminded their } \\
\text { learners the importance of } \\
\text { following tips when studying } \\
\text { for an exam. }\end{array}$ \\
\hline \multirow{5}{*}{ 5. Lorena } & $\begin{array}{l}\text { Negotiating a topic for tutoring (Grammar) } \\
\text { Angela : Hi, ok so what do you want for our } \\
\text { tutorials today ? Do you want school stuff or } \\
\text { do you want to correct some grammar stuff? }\end{array}$ & learning a language. \\
\hline
\end{tabular}

Tutor: Why?

Cami: Because if you have a big goal and small goal, we can create a way in order to create a structure. Between that small goal and big goal that you are creating like a structure, so I think it is quite nice because that first point would be the small goal and the second point would be the big goal. We can produce... we can find too many things. (emergent code: evaluation of self-learning strategy)

Cami: I mean, for example my biggest goal is to try to understand the present perfect tenses (emergent code: emergent code: establishment of self-learning objective)

Tutor: That is grammar... (emergent code: validation from the tutor's code)

Cami: Yeah, I know I have a kind of obsession for the grammar. (emergent code: establishment of selflearning objective)

Tutor: Well, that is not wrong. (emergent code: validation from the tutor's code)

Cami, participant 7, knows how to tackle tasks. Cami shows awareness that a plan is needed. He voices the strategy of moving from the parts to the whole for language development. On the other hand, he reaffirms his teacher identity to explain his beliefs and behaviors. In Table 5, excerpts from participants 6, 7, 8, and 9 exemplify the accounts of the conversations that reveal or shape goal-setting behaviors. For instance, Cami declared he had his own strategies for before, during and after writing. The dialogues in Table 5 above illustrate the presence of modifying goals, strategies, planning, and self-evaluation, seeking help, responsibility, and organization.

Cami, as most other participating students, claimed that they self-directed their learning when decisions were their responsibility (Holec, 1981). They also had control of selfregulation of cognition and did it when they modified a meta-strategy. The excerpts in Table 
Imelda Zorro Rojas

Table 5. Goal-setting relates directly to SRL

\begin{tabular}{|c|c|c|}
\hline Tutees & Accounts & Interpretation \\
\hline 6. John & $\begin{array}{l}\text { Maria (tutor)and John tutee discuss self-involvement } \\
\text { Tutor: well in this independent practice you arrived } \\
\text { to a self-evaluation process, of reflection, you } \\
\text { review what you were doing well, your strengths } \\
\text { and weaknesses and also established goals, tell us, } \\
\text { how was that? Ok. (Done in Spanish) } \\
\text { Tutee: Well, I started familiarizing with the language and } \\
\text { then I got involved in grammar, listening and speaking. }\end{array}$ & $\begin{array}{l}\text { Helping learners to discover } \\
\text { the importance of self- } \\
\text { regulating contributes to } \\
\text { becoming active participants. } \\
\text { Code: Self-evaluation } \\
\text { Level of autonomy: Compromise }\end{array}$ \\
\hline 7. Cami & $\begin{array}{l}\text { Awareness of a process. } \\
\text { Participant stressed the importance of } \\
\text { tutoring sessions, and expressed strong } \\
\text { beliefs on grammar acquisition. } \\
\text { "Because if you bave a big goal and a small goal, we } \\
\text { can create a way in order to create a structure." }\end{array}$ & $\begin{array}{l}\text { Adapting goals to needs demands } \\
\text { self-awareness. Reflection on } \\
\text { strategies assists instructors } \\
\text { in discovering beliefs. } \\
\text { Code: Identification of self- } \\
\text { learning objective. } \\
\text { Level of autonomy: Awareness } \\
\text { \& Transcendence }\end{array}$ \\
\hline 8. Karen & $\begin{array}{l}\text { Interest in grammar (Tutor, María) } \\
\text { Getting involved in tutoring sessions allowed me } \\
\text { reinforce grammar aspects to be confident, and } \\
\text { gradually start being more familiarized with the } \\
\text { language to participate in conversations" }\end{array}$ & $\begin{array}{l}\text { Smaller goals gradually lead } \\
\text { tutees to fulfill bigger goals. } \\
\text { Code: Beliefs about learning the language. } \\
\text { Level of autonomy: Awareness } \\
\end{array}$ \\
\hline 9. Angie & $\begin{array}{l}\text { Planning the learning process } \\
\text { Tutor: Today is March 10th, we are here with our } \\
\text { student Angie. She has come to the second tutoring } \\
\text { session. According to the format I gave her last } \\
\text { time, [and] based on a plan of work, I'm going to } \\
\text { check. to see how she did during the first week. } \\
\text { Then we're going to set new goals. I mean } \\
\text { objectives to start working weekly. } \\
\text { Tutor: Hi, Angie: How did it go with your } \\
\text { learning objective this week of review? } \\
\text { Tutee: Well, I have been looking for many ways of learning. } \\
\text { Tutor: And what was your objective, your } \\
\text { learning goal this week that just ended. } \\
\text { Tutee: I wrote that my difficulty was comprehension when } \\
\text { answering questions: that was my objective. Uhm... } \\
\text { Tutor: How to formulate and understand questions? }\end{array}$ & $\begin{array}{l}\text { Maria, the tutor, } \\
\text { suggested strategies. } \\
\text { For study habits, she did } \\
\text { individual and group follow-up. } \\
\text { Code: Identification of self- } \\
\text { learning objective } \\
\text { Level of autonomy: Intervention }\end{array}$ \\
\hline
\end{tabular}


5 suggest that participants had advanced in tackling tasks and awareness on the need of a plan. On the other hand Maria, the tutor, proposed procedures and strategies to Angie, John, and Karen. María stated that for enforcing study habits, she followed up individually in her English class, and that this favored rapport and brought positive changes.

Similarly, Maria held a dialogue with Angie, participant 9: First, on 'many ways of learning' and second, on the difficulties to understand questions. Goal-setting allowed her to communicate better and to commit to a course of action.

Finding 3: The provision of enactive feedback relates directly to SLR. Enactive feedback, understood as seeking a reaction to the content and procedures of learning, proved positive in the construction of SRL. This feedback helped adjusting objectives, ways of doing, and behaving. With quality feedback, tutors were able to keep track of the tutees' performance and allowed them to observe how they advanced. The exchange below between tutor Marina and a tutee reflects attempts to promote self-regulation. Clarification and elicitation techniques and a teacher-initiation student-response pattern stand out. The tutor clarified the differences between passive voice and causative forms.

Tutor Marina: Well, last class we saw causative forms, right? Here you have two samples - showing the exam: "I had my essay marked" and another one was "The essay was marked by the teacher". What did you understand about these? Are these causative forms? Besides, in class we were mentioning if these two sentences were similar or different.

Tutee: I understood that both were similar and that the explanation of have related to the responsibility the teacher assigned.

Tutor Marina: uhm... (Backechannel)

Tutee: My doubt had to do with two similar topics we studied last term: embedded questions and... and eh, I forgot me $\ldots$ ah $\ldots$ and passive voice.

Tutor Marina: The second one is passive voice, right? They talk about the example: My essay was marked by the teacher, then let us remember how it is formed, here it is passive voice: no embedded questions (subordinated questions) not, because these are not questions. The examples that we saw are not questions, right? Then this one is passive voice. How ... how do you make a sentence? What is the grammar pattern? What would be this? (The teacher shows the exam) (Emergent code: grammar clarification)

Tutee: The subject

Tutor Marina: Uhm (emergent code: validation from the tutor)

Tutee: the verb

Tutor Marina: But what verb is this one?

Tutee: Past

HOW Vol. 26, No. 2, July-December 2019, ISSN 0120-5927. Bogotá, Colombia. Pages: 33-57.. 
Imelda Zorro Rojas

Tutor Marina: What Verb?

Tutee: Ah... been (past participle)

Tutor Marina: Uhm, remember we use causative form when we want to imply anotherperson, remembered the assistant explained that... when we want to say that somebody causes or ask somebody to do something. This structure differs from Spanish; I had my essay marked; which means that you asked your teacher to correct your essay. (Emergent code: grammar clarification)

In this feedback, clarification of grammar prevails. Scaffolding with elicitation techniques allows the tutee to keep the floor to clarify the differences between "causative form and passive voice." The backchannel 'uhm...' allows the provision of more explanation on doubts.

The following excerpt, offered by Yanis who was the tutor, and a group of 6 tutees, reflects their thinking about taking an exam:

Tutor Yanis: My question is... You mean simple details... (Emergent code: belief about teaching a foreign language)

Tutee 4: You need concentration. (Emergent code: intervention)

Tutor Yanis: Ok, you need more concentration and not being overconfident. Ok I advise proofreading carefully for next time. Ok, that the first part of the analysis and we have.... uh... I want to pass to that part of writing, all right and I want to read the instructions, imagine that you are the man or the woman in the picture (showing a picture) correct? In addition, write about "a meeting" and don't forget the verbal tenses.... and did you notice that at the end there was a check. list, did you see it... when you were having the exam? Did you notice the check list? Or you did not. Yanis confirmed that the strategies or tips raise awareness of ways to answer and to reduce mistakes.

Yanis, the tutor, reminds tutees of the pointers for taking an exam. Yanis stressed strategy use and awareness to 1) proofread, 2) follow instructions, 3) pay attention to visuals in exams to know your role, 4) check verb tenses.

Table 6 provides the accounts and interpretations of data gathered about feedback.

The tutors' provision of feedback intends that students grasp language use. Tutor Leidy offers several examples to Amanda, participant 10, and so does Tutor Marina with participant 12. Feedback was also provided on the procedures to tackle the foreign language. Tutor Aida focused on the actions that Natalia had taken or not taken to enhance her language proficiency. That is an example of promotion of SRL with enacting feedback.

Finding 4: Scaffolding relates directly to SRL. Scaffolding makes up part of Vygotsky's concept of the Zone of Proximal Development (ZPD) (Vygotsky, 1978). He suggests that learning occurs when production is stretched through required skillful assistance at points in the learner's ZPD. This zone depends on individual characteristics such as motivation, self- 
Table 6. Principle three: Provision of Enactive Feedback relates directly to SRL

\begin{tabular}{|c|c|c|}
\hline Tutees & Accounts & Interpretation \\
\hline $\begin{array}{l}10 . \\
\text { Amanda }\end{array}$ & $\begin{array}{l}\text { Grammar points. } \\
\text { Tutor Lady listens to her tutee Amanda giving } \\
\text { an example in present continuous... } \\
\text {-Ok. "I am saving," that's correct. Why am I saving? } \\
\text { Because it's a thing in progress. You are doing it. Ok, so, } \\
\text { if you notice we have talked about present simple and I } \\
\text { ask you, what do you do? Present simple. You said "I work } \\
\text { for city bank", Stefany said, "I work as a secretary", and } \\
\text { Lina said I work in Caracol, and Karina said I look after } \\
\text { children. Correct? So, that's present simple. Nevertheless, } \\
\text { Lina now said, when I ask, what you use the money for. } \\
\text { In addition, she said I am saving for vacation, so, in this } \\
\text { moment she is working and she is saving the money, } \\
\text { because it is a continuous action in simple present. }\end{array}$ & $\begin{array}{l}\text { Recapitulation of } \\
\text { verb tenses, such as } \\
\text { present simple, eases } \\
\text { the understanding of } \\
\text { present continuous. } \\
\text { Code: Grammar } \\
\text { Clarification } \\
\text { Level of autonomy: } \\
\text { Awareness }\end{array}$ \\
\hline $\begin{array}{l}11 . \\
\text { Natalia }\end{array}$ & $\begin{array}{l}\text { Follow-up on a study plan } \\
\text { Tutor Aida: Tell me Natalia, and which } \\
\text { has been your intervention plan. What } \\
\text { have you done to fulfill your goals? } \\
\text { Tutee: Well, my goal was speaking, eh... well I started } \\
\text { talking to myself, let's say like telling myself about what } \\
\text { I have done the previous day. I did it because I do not } \\
\text { have nobody to talk with, so I did it on my own. } \\
\text { Tutor: And you have a recording about it? } \\
\text { Tutee: No, I was going to record it } \\
\text { Tutor: That would be interesting }\end{array}$ & $\begin{array}{l}\text { The tutor followed up } \\
\text { the feedback provided } \\
\text { to Natalia and realized } \\
\text { she has started a } \\
\text { plan on her own. } \\
\text { Code: Identification of } \\
\text { self-learning objective. } \\
\text { Level of autonomy: } \\
\text { Intervention \& Creation }\end{array}$ \\
\hline $\begin{array}{l}12 . \\
\text { George }\end{array}$ & $\begin{array}{l}\text { Marina, the tutor, explains the use of } \\
\text { causative forms and passive voice. }\end{array}$ & $\begin{array}{l}\text { Codes: Grammar } \\
\text { clarification }\end{array}$ \\
\hline
\end{tabular}

esteem, anxiety level, risk-taking ability, styles, and strategies. These individual differences are major, relating both to cultural background and to individual personalities (Scarcella \& Oxford, 1992; Castillo, 2014). As evident in Table 7, the participating students required diverse assistance: some in language points, others in exam preparation, and others in speaking. Individual differences accounted for the need of scaffolding to transform their ways of understanding, the curricula and their practices.

The transcription of the dialogue between assistant Nelly, who is a native English language speaker, and Mike, illustrates scaffolding. Mike drafted a poem and worked on it 
Table 7. Principle 4. Scaffolding relates directly to SRL

\begin{tabular}{|c|c|c|}
\hline Tutees & Accounts & Interpretation \\
\hline 13. Ana & $\begin{array}{l}\text { Preparing an oral exam, interest in speaking. } \\
\text { Expressed belief that language acquisition } \\
\text { means taking risks while speaking. } \\
\text { Tutor (Aida): Why are you afraid of speaking? } \\
\text { Tutee: Because sometimes there are many } \\
\text { people that laugh at me. So, I feel... } \\
\text { Tutor: Embarrassed. Even if you are } \\
\text { working with your small group? } \\
\text { Tutee: Here? No, with this group } \\
\text { but with another group yes. } \\
\text { Tutor: Tape your rehearsals using your cellphone so you } \\
\text { can improve a lot; also search for help with a partner. }\end{array}$ & $\begin{array}{l}\text { Trying out and rehearsing prior } \\
\text { to a speaking activity helps } \\
\text { to put aside fears, in this case } \\
\text { speaking in front of everybody. } \\
\text { Code: Belief about } \\
\text { learning the language. } \\
\text { Level of autonomy: } \\
\text { Awareness }\end{array}$ \\
\hline 14.Ximena & $\begin{array}{l}\text { Preparing for a written exam. Before } \\
\text { writing a story, should I write a } \\
\text { title, or how should I do? } \\
\text { Aida: "You should follow the instructions, here } \\
\text { (Tutor points the instruction) "write and answer } \\
\text { to one of the questions from seven to eight," } \\
\text { you decided on exercise seven, right?" }\end{array}$ & $\begin{array}{l}\text { Following instructions on a } \\
\text { piece of writing, make students } \\
\text { aware of being successful; } \\
\text { also following a guideline } \\
\text { Code: Pathway build up } \\
\text { Level of autonomy: } \\
\text { Awareness }\end{array}$ \\
\hline 15. Karol & $\begin{array}{l}\text { Using module pack, establishing } \\
\text { goals, showing evidences. } \\
\text { Tutee: First of all, for me was very interesting } \\
\text { this way of learning English, because eh I didn't } \\
\text { know this method where you can distribute } \\
\text { your time, your skills in like a plan. }\end{array}$ & $\begin{array}{l}\text { Planning helped } \\
\text { participants with time } \\
\text { management to advance. } \\
\text { Code: Awareness } \\
\text { Level of autonomy: } \\
\text { Awareness }\end{array}$ \\
\hline 16. Vicky & $\begin{array}{l}\text { Need for speaking (Use of diverse sources) } \\
\text { Tutee: Ah. I want to improve the speaking. And for } \\
\text { this, I use the internet, the New York. times, or other... } \\
\text { Tutor (complements)... Sources. } \\
\text { Tutee: Yeah, Sources. Eh, topics that can belp } \\
\text { me with vocabulary. And if I speak in French or } \\
\text { in English, it could help me. Every day I watch } \\
\text { the ART program, it's an alternative a means of } \\
\text { communication. It is so good because you can find } \\
\text { videos or news around the world. It is very good. }\end{array}$ & $\begin{array}{l}\text { Materials and resources } \\
\text { enhance understanding and } \\
\text { provide a variety of ways } \\
\text { to acquire knowledge. } \\
\text { Code: Beliefs about speaking } \\
\text { a foreign language. } \\
\text { Level of autonomy: } \\
\text { Intervention }\end{array}$ \\
\hline
\end{tabular}




\begin{tabular}{|c|c|c|}
\hline Tutees & Accounts & Interpretation \\
\hline 17.Yeimmy & $\begin{array}{l}\text { Building a learning pathway } \\
\text { (Use of internet websites). } \\
\text { Tutee: The teacher showed us a method and also } \\
\text { the page where we can improve, we can find ways, } \\
\text { articles that help me discover the best way to learn. } \\
\text { In this moment, I have done activities with this } \\
\text { plan. I have seen... eh.... ¿Como se dice? } \\
\text { Tutor: Better? Better resources. } \\
\text { Tutee: Yes, that's right. }\end{array}$ & $\begin{array}{l}\text { The use of virtual materials } \\
\text { and a guide to use them } \\
\text { contributes to academic success. } \\
\text { Code: Pathway build up } \\
\text { Level of autonomy: } \\
\text { Intervention }\end{array}$ \\
\hline 18. Mike & $\begin{array}{l}\text { Need for demonstrating creativity } \\
\text { by means of writing. } \\
\text { Feedback on a poem with an English } \\
\text { assistant. Expresses beliefs on the mastery } \\
\text { of language as a venue of expression. }\end{array}$ & $\begin{array}{l}\text { The level of autonomy } \\
\text { (Nunan, 1997) presented in } \\
\text { Mike is between two levels: } \\
\text { creation and transcendence. } \\
\text { Code: Transcendence }\end{array}$ \\
\hline
\end{tabular}

with her; they moved from a focus on language to a focus on meaning and expression for understanding rhythm and intonation in a poem. This is Mike's attempt to write a poem:

$$
\begin{gathered}
\text { Beauty and the beast } \\
\text { Beauty and the maiden with deep blue eyes } \\
\text { seeking her nice tights, } \\
\text { beauty and snow white with her snowed smile } \\
\text { beauty and the fake princess from whom the ashes rise* } \\
\text { the cast spell on the king son, } \\
\text { beauty is the maiden that makes a beast fight } \\
\text { and go to work and fight six demons until they are killed, } \\
\text { beauty is the girl who loves the beast and no matter how they } \\
\text { she will defeat the beast } \\
\text { you are my beauty girl and yeab with deep eyes } \\
\text { you can *her next tights and know what's a smile, } \\
\text { you are my princess you are my princess } \\
\text { not fake though, for you love this beast } \\
\text { even though I am not the king son }
\end{gathered}
$$

Mike's interest in writing a poem made him thrive. Initially, he focused on language, and as the session advanced, the focus shifted to metrics and alliteration. Tutor Nelly scaffolded as follows, "I mean, it is your poem so you can do whatever you want, right? And like you said you don't have a specific meter, here it does have a rhythm." With scaffolding, Mike was able to read his poem 
with rhythm. Mike said... "Yeah. But I don't know if when I was reading, I actually would pronounce the word, so that's why I'm asking you to help me." Mike's words indicated that he is monitoring himself:

Mike: No, I just write it, I mean, I just try to listen to myself, and if it has a rhythm or something like that I would be like "oke it's cool," but I don't know like any pattern or any rule to compose these things.

Mike's effort to draft a poem brings us close to Bakhtin's (1981) idea of a voice that attempts to transcend, that is, the voice of the mind. The topic of Beauty and the Beast in Mike's voice transcends with a universal and social voice, a category that Bakhtin (1981) named ventriloquation, the secret speech of other.

Mike's autonomy level appears to oscillate between creation and transcendence (Nunan, 1997). Creation represents a step to heteronomy, which the tutor validated, "It is your poem and you can do whatever you want." On the other hand, the level of transcendence indicates selfdetermination for Mike to modify his behavior.

The following excerpt also shows how scaffolding established a link between instructors and the use of materials (Lantolf, 2000). Talía and Naty interacted with their Tutor Aida to talk about vocabulary in context. The emerging codes refer to constructing a pathway and using materials.

Tutor Aida: We tried to see it, because I had the movie in Blue-ray. Well, we are going to see the episode that you were telling me. What else do you do for a listening activity?

Tutee Naty: Well, sometimes I do different things, first I listen to the...

Tutee Talía: The passage and then I read the questions about that or sometimes I do the same as Nata said before.

As a researcher of this project, I participated in twenty sessions that stressed explanation, reflections, strategy use, goal-setting, scaffolding, and feedback. The tone of the sessions indicated a relationship of equals and revealed a climate of trust (Wells, 2001; Luidig \& Mynard, 2012). The 18 participating students' self-regulated by controlling the resources, and the use of artifacts which promoted acquisition (Lantolf, 2000). The tutees' expected success somehow depended on how tutors scaffolded. Table 5 summarizes the salient tutor's 50 dialogic strategies.

The tutor Maria participated in seven sessions which concentrated on identifying and meeting goals, while Marina's contribution stressed reflection on the acquisition process, and feedback focused on testing and on grammar. As a tutor, Yanis participated in two sessions in which she focused on test taking. On the other hand, the two English language nativespeaker tutors, Nelly and Angy, reinforced pronunciation and grammar in writing. Following Zimmerman (as cited in Boerkaerts, Pintrich, \& Zeidner, 2005), part of the negotiation arises 
Table 7. Tutors' prevalent dialogic strategies in forty sessions

\begin{tabular}{|c|l|l|}
\hline & \multicolumn{1}{|c|}{$\begin{array}{c}\text { TUTORS } \\
\text { (Pseudonyms) }\end{array}$} & \multicolumn{1}{c|}{ Tutors' main dialogic strategies } \\
\hline 1 & Aida (20 Sessions) & $\begin{array}{l}\text { Explanations, reflections, suggestion of strategies, } \\
\text { development of a learning plan, and scaffolding. }\end{array}$ \\
\hline 2 & María (7 Sessions) & $\begin{array}{l}\text { Reflections, suggestion of strategies and } \\
\text { development of a learning plan. }\end{array}$ \\
\hline 3 & Marina (3 Sessions) & $\begin{array}{l}\text { Explanations and reflections, and } \\
\text { scaffolding of grammar points. }\end{array}$ \\
\hline 4 & Nelly (2 Sessions) & Scaffolding \\
\hline 5 & Angy (2 Sessions) & Negotiation of topics. \\
\hline 6 & Yanis (2 Sessions) & Reflections, and giving tips for test taking \\
\hline 7 & Lady (2 Sessions) & Clarifications of grammar points \\
\hline 8 & Claudia (2) & Determining topics for tutorial sessions \\
\hline
\end{tabular}

from the students' interest in one topic, in this case grammar, and the tutors' assurance to provide explanations. The academic behavior is adapted in the interaction.

The focus groups of eight instructors agreed that dialogic tutoring constituted an innovation; they pointed out that environmental factors had to be taken into account as well. They added that the use of campus facilities, materials, and resources should involve the active participation of instructors and the support of the university administration. The new pedagogical practices required training and willingness to change from lecturing to becoming a guide. In the students' point of view, self-regulation and autonomy go hand in hand since change depends on the students' volition.

\section{Conclusions}

This study addressed self-regulation and its related aspects of behavior, heteronomy, motivation, strategy use, and agency. The purpose of the pedagogical intervention was to identify the principles that foster the SRL of another language. The diagnosis revealed that the participants' lack of strategies and goals required the attention of the instructors. There was a need to enhance current practices and this meant listening to the tutees' voices.

It was not enough to be aware of purpose and implications in decision-making, action and evaluation; the teaching and the curriculum needed to promote cognitive and metacognitive knowledge. This fact coincides with the findings by Cuesta et al. (in Banegas, 
2017). The study provided evidence that dialect tutoring constitutes an effective mediation to build SRL. Participants understood the purpose of their course and, as well, they explicitly accepted responsibility, negotiated objectives, took initiative in planning and executing tasks, and regularly reviewed and evaluated their acquisition processes. The data suggest that knowledge transcended the classroom. There was a consensus among participants that SRL demanded a positive attitude, a capacity for reflection, and a readiness to be proactive in selfmanagement and in interaction with others (see also Sabitha, 2013).

Data also indicated that the epistemological understanding between the instructors and the participating undergraduates helped achieve a re-interpretation of roles. The attitude of inquiry and discovery of new ways to approach self-regulation encouraged tutees to seek help. Both learners and instructors were in the capacity of discharging their traditional roles (Holec, 1981).

Furthermore, tutors extended the meaningful use of resources and strategies. The participating students not only self-regulated but also co-constructed what happened. The relationship between tutor and tutee redefined their roles, their ways of working, and the use of resources. In sum, the co-construction of self-regulation influenced individual behaviors. The promotion of self-regulation through dialogic tutoring helped learners to act and explore possibilities that had not been part of their language acquisition. These possibilities promoted interest; they brought a sensation of achievement that also encouraged motivation.

On the other hand, scaffolding of learning contributed to self-regulation and with it, to redefining a course of action successfully. Teacher feedback for learners to act upon language use, language acquisition processes and procedures, proactive behaviors, strategies and resources contributed to goal attainment (Castillo, 2014). In addition, dialogic tutoring recovered feedback as a two-way communication process; tailored to the individual thus creating a positive classroom climate.

This study complements the theoretical components proposed by Zimmerman (in Boerkaerts et al., 2005) that conceives SRL as a social cognitive perspective resulting from an interaction of personal, behavioral, and environmental factors. In this study, dialogic tutoring, feedback, and scaffolding allowed deeper knowledge of SRL. This research report contributes to the discussion on how SRL can be mediated by a social construction, which enhances cognitive and metacognitive aspects already identified in the literature (Thanasoulas, 2000). Students and instructors co-constructed self-regulation via dialogic tutoring. The presence of a helpful tutor, sensitive to the learners' needs, interests and personal agency beliefs facilitated goal-setting. Furthermore, scaffolding instruction and provision of feedback on both the language, and on the misbeliefs about learning, paved the road towards autonomy. 


\section{References}

Banegas, D. L. (Ed.) (2017). Initial English language teacher education: International perspectives on research, curriculum and practice. London: Bloomsbury Academic.

Bakhtin, M. M., \& Holquist, M. (1981). The dialogic imagination: Four essays. Austin: The

University of Texas. 268-422.

Benson, P. (2001). Teaching and researching autonomy in language learning. Harlow: Longman Pearson Education.

Benson, P. (2011). What is new in autonomy? The Language Teacher, 35(4), 15-18.

Boerkaerts, M., Pintrich, P. R., \& Zeidner, M. (Eds.) (2005). Handbook of self-regulation. San Diego, CA: Academic Press.

Castillo, R. (2014). Teaching and learning another language strategically. Bogotá: Universidad Distrital Francisco José de Caldas.

Freire, P. (1970). Pedagogy of the oppressed. New York: The Continuum International Publishing Group Inc.

Gardner, D., \& Miller, L. (1996). Taskes for independent language learning. Cambridge: Cambridge University Press.

Gu, Y. (2010). The strategic self-regulation (S2R) Model of Language learning. London: Pearson.

Harris, L., Brown, G. T. L., \& Dargusch, J. (2018). Not playing the game: Student assessment resistance as a form of agency. The Australian Educational Researcher, 45 (1), 125-140.

Holec, H. (1981). Autonomy in foreign language learning. Oxford: Pergamon.

Kanda University (2007). Module packs available. Accessed 1 April 2018 from: https://salcnews. wordpress.com/tag/modules/

Kluwe, R. H. (1987). Executive decisions and regulation of problem solving behavior. In F. E. Weinert \& R. H. Kluwe (Eds.) Metacognition, motivation, and understanding (pp. 31-63). Hillsdale, NJ: Lawrence Erlbaum.

Lantolf, J. (2000). Sociocultural theory and second language learning. Oxford: Oxford University Press.

Lantolf, J. P., \& Pavlenko, A. (2001). Second language activity: understanding learners as people. In M. Breen (Ed.), Learner contributions to language learning: New directions in research (pp. 141-158). London: Pearson.

Gathercole, I. (Ed.) (1991). Autonomy in language learning. London: CILT.

Luidig, C., \& Mynard, J. (Eds.) (2012). Autonomy in Language Learning: Advising in Action IATEFL. New York: Darwin College.

Magno, C. (2009). Self-regulation and approaches to learning in composition writing in English. TESOL Journal, (1), 1-16.

McGarry, D. (1995). Learner autonomy: The role of authentic texts. Dublin: Authentik. 
Imelda Zorro Rojas

Mynard, J., \& Carson, L. (2013). Advising in language learning, dialogue, tools and context. London \& New York: Pearson.

Nakata, Y. (2014). Self-regulation: Why is it important for promoting learning autonomy in the school context? Studies in Self-Access Learning Journal, 5(4), 342-356.

Nunan, D. (1997). Does learner strategy training make a difference? Modern languages, 24, 123-142.

Oekaerts, M., Pintrich, P., \& Zeider, M. (2005). Handbook of self-regulation. London: Academic Press.

Sarangi, S. (2000). Activity types, discourse types and interactional hybridity: The case of genetic counseling. In S. Sarangi \& M. Coulthard (Eds.). Discourse and Social Life (pp. 1-27). London: Pearson.

Sabitha, S. R. N. (2013). Learner autonomy in language learning. Social and Behavioral Sciences, Vol. $70,1238-1242$.

Scarcella, R. C., \& Oxford, R. L. (1992). The tapestry of language learning: The individual in the communicative classroom. Boston: Heinle \& Heinle.

Straus, A., \& Corbin, J. (2002). Bases de la investigación cualitativa. Técnicas y procedimientos para desarrollar la Teoría Fundamentada. Medellín: Universidad de Antioquia.

Thanasoulas, D. (2000). What is learner autonomy and how can it be fostered? The Internet TESL Journal, Vol. VI, 11, 1-12.

University of Cambridge (2017). What is Dialogic Teaching? Cambridge: The faculty of Education. Retrieved January 28, 2018 from: https://www.educ.cam.ac.uk/research/projects/dialogic/ whatis.html

Voloshinov, V. (1976). El signo ideológico y la filosofía del lenguaje. Buenos Aires: Nueva Visión.

Vygotsky, L. S. (1978). Mind in society: The development of higher psychological processes. Cambridge: Harvard University Press.

Yamaguchi, A. (2012). Creative tools that facilitate the advising process. In C. Ludwig \& J. Mynard (Eds.), Autonomy in language learning. Advising in action. Canterbury: IATEFL.

Wells, G. (2001). Indagación dialógica. Hacia una teoría y una práctica sociocultural de la educación. Barcelona: Paidós. 


\section{Appendix A. Diagnostic Questionnaire. N=18 Learners}

\section{AUTONOMY IN LANGUAGE LEARNING}

Few learners use English to share opinions with classmates.

Few learners use English outside class.

Students ask for explanations about the topics given in class.

\section{What have you liked the most in class? (Answers to the open question).}

The lessons given by the native speaker assistants

The teacher's commitment

To learn by oneself and share that experience

The activities developed with my teacher

The feedback provided by teachers and partners

To acquire new knowledge

To fulfill my assessment

To develop the class by units

To use the language

To use cross curricular topics

To review the topics

To be aware of my limitations

To use books and grammar books

To develop a pedagogical project

To attend the English club

\section{What have you liked the least in class?}

Not to see our progress

Not to have individualized attention

Not to review the learned topics

Lessons tend to be boring

To be aware that we can fulfill everything

Our teachers' methodology

Lack of determination and autonomy from some of us.

Assume everybody goes at the same pace

Not to work on weaknesses 
Too much use of web pages with no orientation

Not to consider everybody's learning assessment

Not to practice what we have learned

The uncooperative attitude of some teachers

SELF REGULATION

How do you regulate your English language learning?

Using exercises from internet

Chatting with foreigners

Doing repetition of mispronounced words

Studying the feedback

Correcting quizzes in class

Facilitating self-correction

Correcting exams

Doing extra exercises 


\section{Appendix B. Responses to the Final Questionnaire. N=18 Students}

How do you feel about tutoring?

We improve 4

Very well 2

The teacher is friendly 1

Not available $\quad 2$

It's rewarding 3

Attendance is limited to exam preparation $\quad 1$

Provides confidence $\quad 2$

I do not feel shy and afraid as in class $\quad 1$

I clarify doubts 1

I do not need it. $\quad 1$ 